Congressional Fellowship Program Alumni Name Daniel Patrick Moynihan Outstanding Legislator, 103rd Congress

In December 1993 the Alumni Association of the Congressional Fellowship Program selected Senator Daniel Patrick Moynihan as the Outstanding Legislator of the 103rd Congress. The award was presented at a reception July 12, 1994, in the Capitol.

Previous recipients of the Outstanding Legislators awards are: Representative Morris Udall, 96th Congress; Senator Robert Dole, 99th Congress; Representative Thomas Foley, 100th Congress and Senator Richard Lugar, 102nd Congress.

\section{Congressional Fellowship Program Announces 1994-95 Competition Winners}

Political Scientists, Reporters Named APSA Congressional Fellows

The American Political Science Association has announced the winners in the national competition for the 1994-95 Congressional Felloship Program. Following a onemonth orientation seminar, Fellows work full time for nine months as professional staff assistants to members of Congress or congressional committees.

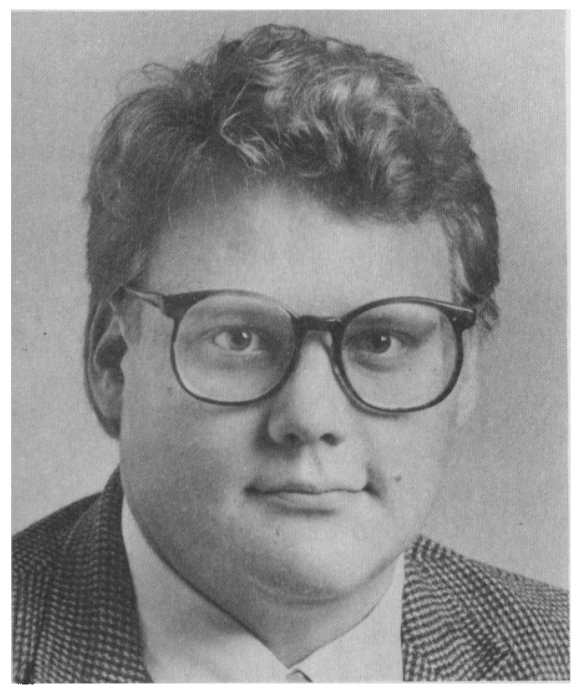

David Eskola

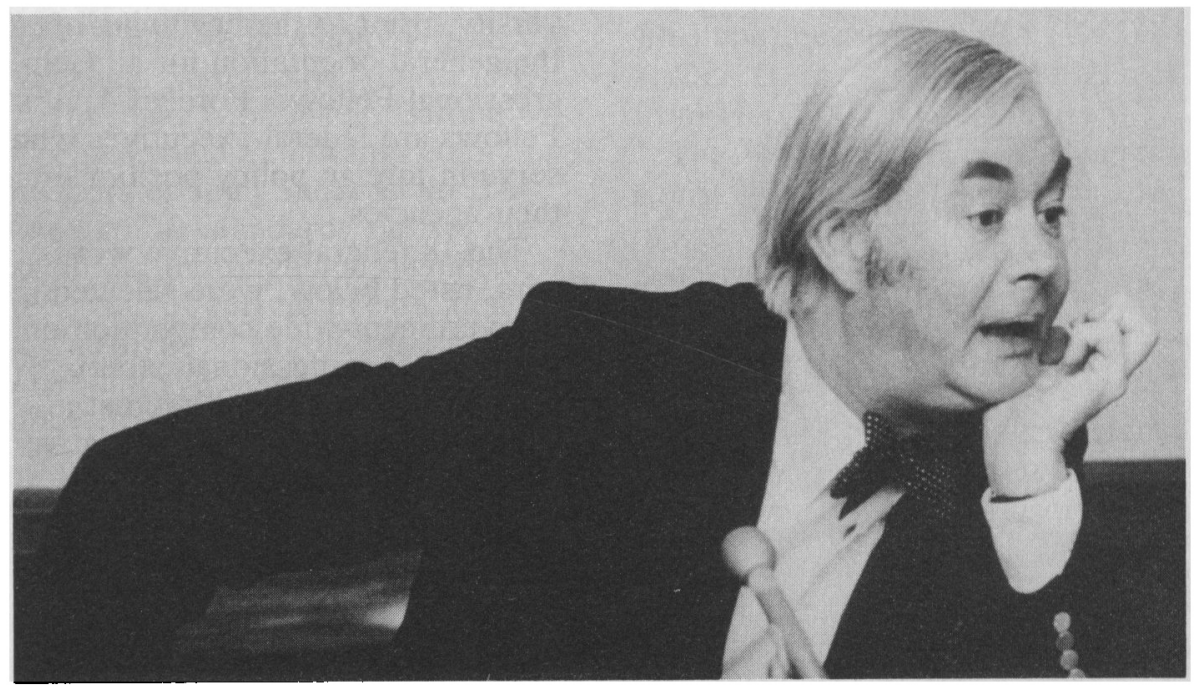

Daniel Patrick Moynihan

The New Political Science and Journalism Congressional Fellows are:

David Eskola, Television Columnist, The Greenville News, Greenville, $\mathrm{SC}$

Kenneth Finegold, Assistant Professor, Department of Political Science, Rutgers University

Douglas Johnson, Senior Producer/ Acting Managing Editor, Michigan Public Radio Network

Robin Kolodny, Assistant Professor, Department of Political Science, Temple University

Forrest Maltzman, Assistant Professor, Department of Political Science, The George Washington University

Stephen McDowell, Sessional Lecturer, Carleton University, Ottawa, Canada

Cheryl Miller, Associate Professor, Department of Political Science and Policy Sciences Graduate Program, University of Maryland, Baltimore County

Lori Nitschke, City Government and Local Politics Reporter, Grand Forks Herald, Grand Forks, ND

Timothy Prinz, Assistant Professor, Government and Foreign Affairs, University of Virginia

Karen Weintraub, Urban Affairs Beat Reporter, Houston Post, Houston, TX

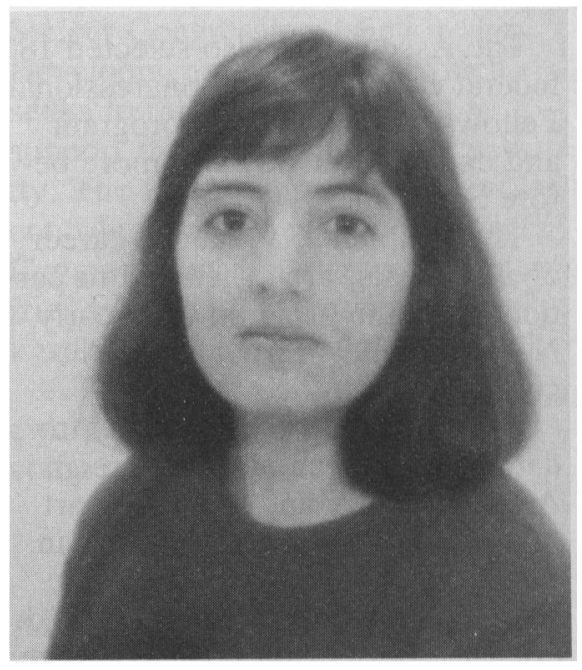

Robin Kolodny

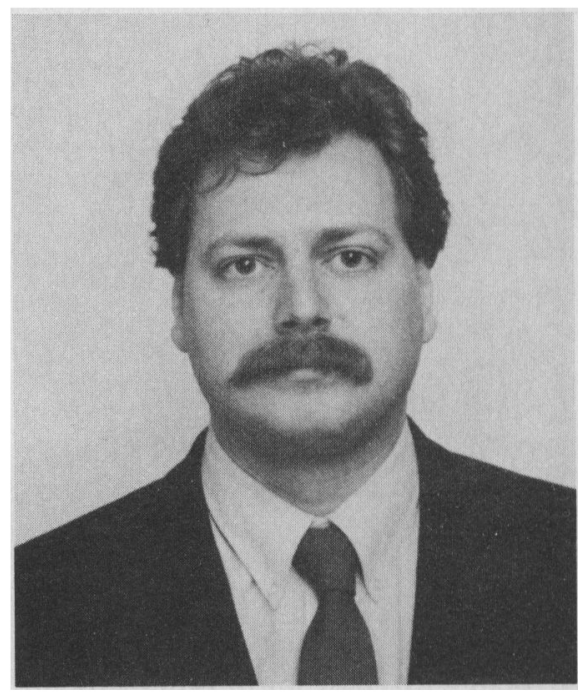

Stephen McDowell 